\title{
Penggunaan Instagram oleh Badan Penanggulangan Bencana Daerah untuk mengoptimalkan destination branding Pangandaran
}

\author{
Priyo Subekti', Hanny Hafiar ${ }^{2}$, Iriana Bakti ${ }^{3}$ \\ ${ }_{1,2,3}$ Universitas Padjadjaran, Bandung, Indonesia
}

\begin{abstract}
ABSTRAK
Perkembangan media sosial yang semakin pesat dan bertambahnya pengguna yang semakin banyak menjadikan media sosial menjadi salah satu sumber rujukan informasi bagi sebagian besar masyarakat. Media sosial telah menciptakan sebuah pola baru dalam berkomunikasi dan berpartisipasi sosial, hal ini dapat dilihat dari banyaknya keterlibatan para pengguna dalam sebuah forum komunikasi atau platform media sosial. Saat ini lembaga pemerintah, swasta dan organisasi masyarakat memanfaatkan media sosial menjadi salah satu media informasi untuk menjangkau masyarakat. BPBD (Badan Penanggulangan Bencana Daerah) Pangandaran memanfaatkan media sosial melalui akun Instagram @pudalopspangandaran untuk memberitakan informasi mengenai kebencanaan, dan kegiatan yang dilakukan oleh BPBD Kabupaten Pangandaran untuk meningkatkan kesadaran masyarakat mengenai kebencanaan. Penelitian ini menggunakan metode deskriptif dengan data kualitatif. Analisis yang digunakan dalam meneliti penggunaan Instagram oleh BPBD Kab. Pangandaran adalah konsep The Circular Model of Some dari Regina Luttrell yang terdiri dari membagikan (share), mengoptimalkan (optimize), mengelola (manage), dan melibatkan (engage). Tingginya potensi bencana di Pangandaran menjadi salah satu latar belakang perlunya meningkatkan kesadaran masyarakat akan kebencanaan. BPBD Kabupaten Pangandaran memanfaatkan Instagram melalui akun@pusdalopspangandaran sebagai media informasi mengenai kebencanaan kepada masyarakat luas. Pengelolaan media sosial yang dilakukan oleh BPBD sudah cukup efektif menjangkau masyarakat khususnya masyarakat Pangandaran, namun terkendala dengan kurangnya sumber daya manusia yang dapat mengelola media sosial agar tetap update.
\end{abstract}

Kata-kata Kunci: Media sosial; Instagram; edukasi bencana; kebencanaan; penggunaan

\section{Instagram account of Badan Penanggulangan Bencana Daerah Pangandaran in optimizing destination branding}

\section{ABSTRACT}

The rapid development of social media and the increasing number of users make social media become one of the sources of reference for information by many people. Social media has created a new pattern in communicating and participating socially, as can be seen from the many involvement of users in a communication forum or social media platform. At present many government agencies, private sector, and community organizations that use social media become one of the media for information to reach the public. BPBD (Regional Disaster Management Agency) Pangandaran utilizes social media through the@ pudalopspangandaran Instagram account to report information on disasters, and activities carried out by BPBD Pangandaran Regency to increase public awareness about the disaster. This study uses descriptive methods with qualitative data. The analysis used in examining Instagram use by BPBD Pangandaran Regency is the concept of The Circular Model of Some from Regina Luttrell, which consists of sharing (share), optimizing (optimize), managing (manage), and involving (engage). The high potential of the disaster in Pangandaran is one of the backgrounds of the need to increase public awareness of disasters. BPBD Pangandaran Regency uses Instagram through the@pusdalopspangandaran account as a medium of information about disaster to the broader community. The management of social media carried out by BPBD has been quite effective in reaching people, especially the people of Pangandaran, but is constrained by the lack of human resources that enable to manage social media update.

Keywords: Social media; Instagram; disaster education; disaster; use

Korespondensi: Priyo Subekti., S.Sos., M.Si. Fakultas Ilmu Komunikasi Universitas Padjadjaran Jl. Raya Bandung Sumedang KM 21, Jatinangor 45363.Email: priyo.subekti@unpad.ac.id 


\section{PENDAHULUAN}

Pertumbuhan media sosial telah sepenuhnya mengubah cara orang berinteraksi dan berkomunikasi (Arora, Bansal, Kandpal, Aswani, \& Dwivedi, 2019). Dengan kata lain pertumbuhan media menimbulkan perubahan dalam masyarakat terutama cara mereka berinteraksi, berkomunikasi, dan merubah pola pencarian informasi mereka. Media sosial menjadi bagian yang sangat penting dalam penyebaran informasi di era digital saat ini karena media sosial mempermudah komunikasi individu dengan karakteristiknya yang dapat melampaui waktu, jangkauan, dan isi pesan, serta bisa dilakukan kapan saja dan dimana saja (Watie, 2017). Dengan hadirnya smartphone, fasilitas komunikasi yang disediakan semakin beraneka ragam mulai dari pesan teks, chatting, grup komunikasi, browsing serta fasilitas media sosial. Media sosial dapat merubah cara berkomunikasi individu (Reza, 2016).

Media sosial terus mengalami perkembangan yang diiringi dengan konvergensi media. Konvergensi media dicirikan dengan bersatunya layanan telekomunikasi, teknologi informasi, dan penyiaran. Konvergensi media tidak hanya berbicara mengenai perkembangan teknologi, tetapi ikut memengaruhi ideologi dalam bidang industri, budaya dan sosial yang ditandai dengan perubahan cara mencari informasi, dan selanjutnya memengaruhi perubahan gaya hidup, karir, bisnis, budaya dan sendi kehidupan (Adhrianti, 2016). Perubahan individu dalam berinteraksi dengan orang lain

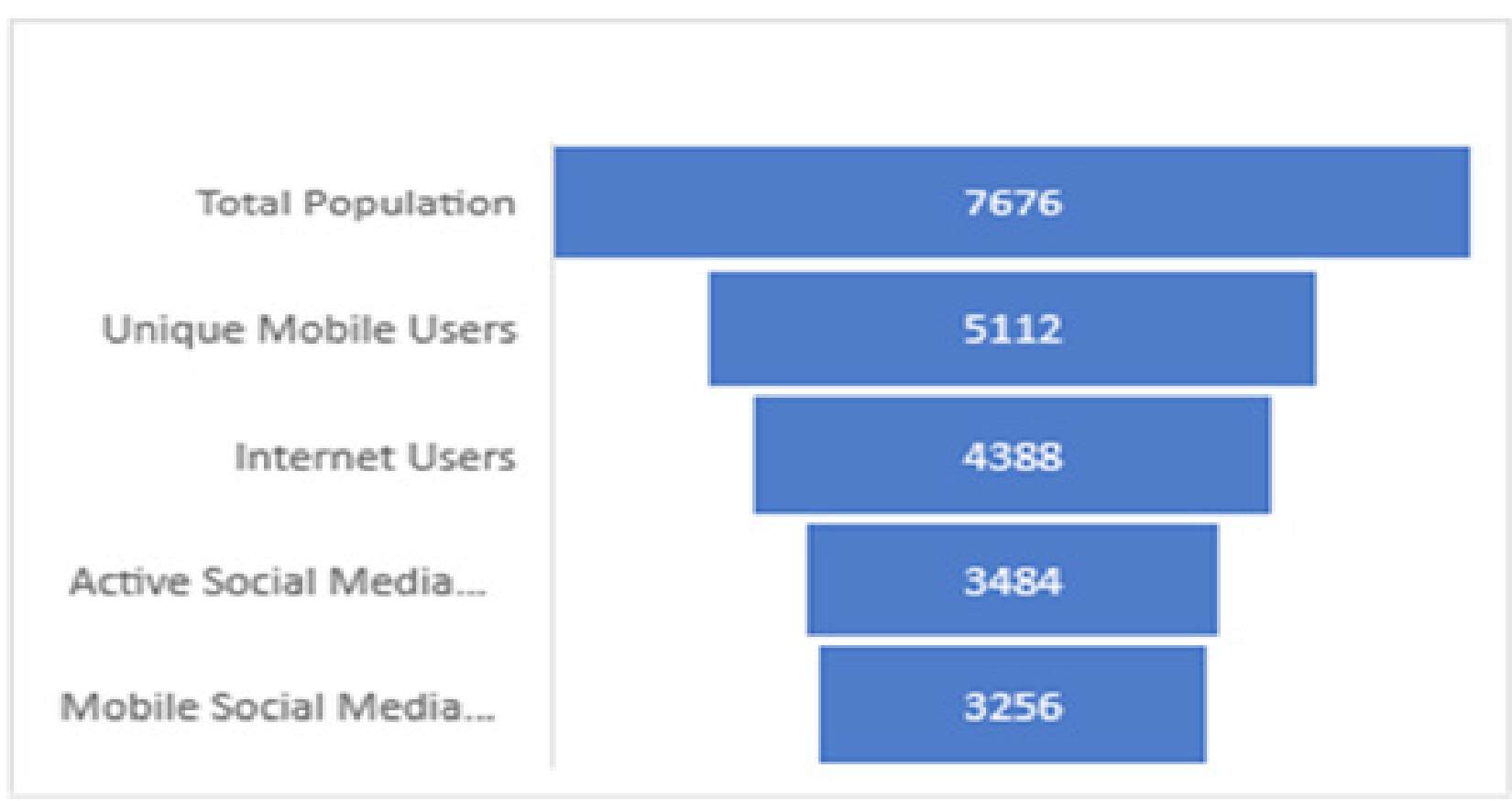

Sumber: Global Digital Report, 2019

Gambar 1 Penggunaan Media Digital di Seluruh Dunia Tahun 2019 
menggunakan berbagai platform media sosial yang menciptakan pengalaman baru, bentuk interaksi sosial baru dan rujukan informasi baru disebabkan oleh konvergensi media. Data penggunaan media digital di seluruh dunia dapat dilihat pada gambar 1 .

Melihat karakteristik media sosial dan konvergensi media yang memengaruhi pola komunikasi individu juga berdampak pada berbagai sektor masyarakat tidak terkecuali sektor pariwisata. Kecenderungan masyarakat dalammelakukan konsumsi informasi pariwisata sedikit banyak telah bergeser seiring dengan perkembangan media sosial (Trihayuningtyas, Wulandari, Adriani, \& Sarasvati, 2018).

Mobilitas wisatawan juga terdorong dengan adanya promosi daerah wisata melalui media sosial. Dahulu masyarakat mencari informasi mengenai destinasi wisata melalui program televisi, majalah atau dari pengalaman orang lain yang pernah berkunjung ke suatu tempat. Namun dalam kurung waktu 15 tahun terakhir, masyarakat mulai menggunakan media Internet termasuk media sosial untuk mencari informasi mengenai destinasi wisata (Hidayatullah, Maya, Sabrina, Artanti, \& Kania, 2018). Hal ini disebabkan karena di dalam sosial media informasi disajikan secara lengkap yang berisi foto dan video serta dapat diakses langsung oleh pengguna media sosial sebagai calon wisatawan. Dari perspektif pengguna media sosial, informasi mengenai destinasi wisata dapat dengan mudah diperoleh (Wijaya, 2016). Secara khusus jika dilihat dari industri pariwisata, citra daerah wisata juga terbangun melalui media sosial.

Salah satu media sosial yang dapat digunakan sebagai sarana promosi destinasi wisata adalah Instagram. Instagram merupakan media sosial yang mengalami perkembangan yang sangat pesat. Penggunaan Instagram aktif tahun 2013-2018 dapat dilihat pada gambar 2.

Instagram adalah platform media sosial yang sering digunakan untuk mengunggah pesan bersifat visual. Instagram menyediakan pesan yang bersifat gambar. Hal ini dapat memberikan gambaran umum secara visual kepada pengguna tanpa harus datang atau melihat langsung secara fisik (Casaló, Flavián, \& Ibáñez-Sánchez, 2018). Salah satu indikator populer tidaknya sebuah foto dalam Instagram dilihat dari jumlah like dan jumlah followers, semakin banyak like yang didapatkan, semakin besar kesempatan foto tersebut masuk ke halaman explore semua pengguna Instagram termasuk yang bukan followers. Namun, jumlah followers memberikan andil paling besar dalam membuat sebuah foto yang diunggah populer. Karena semakin banyak followers, maka semakin besar juga kesempatan pengguna lain memberikan like dengan banyaknya pengguna yang melihat foto tersebut. 


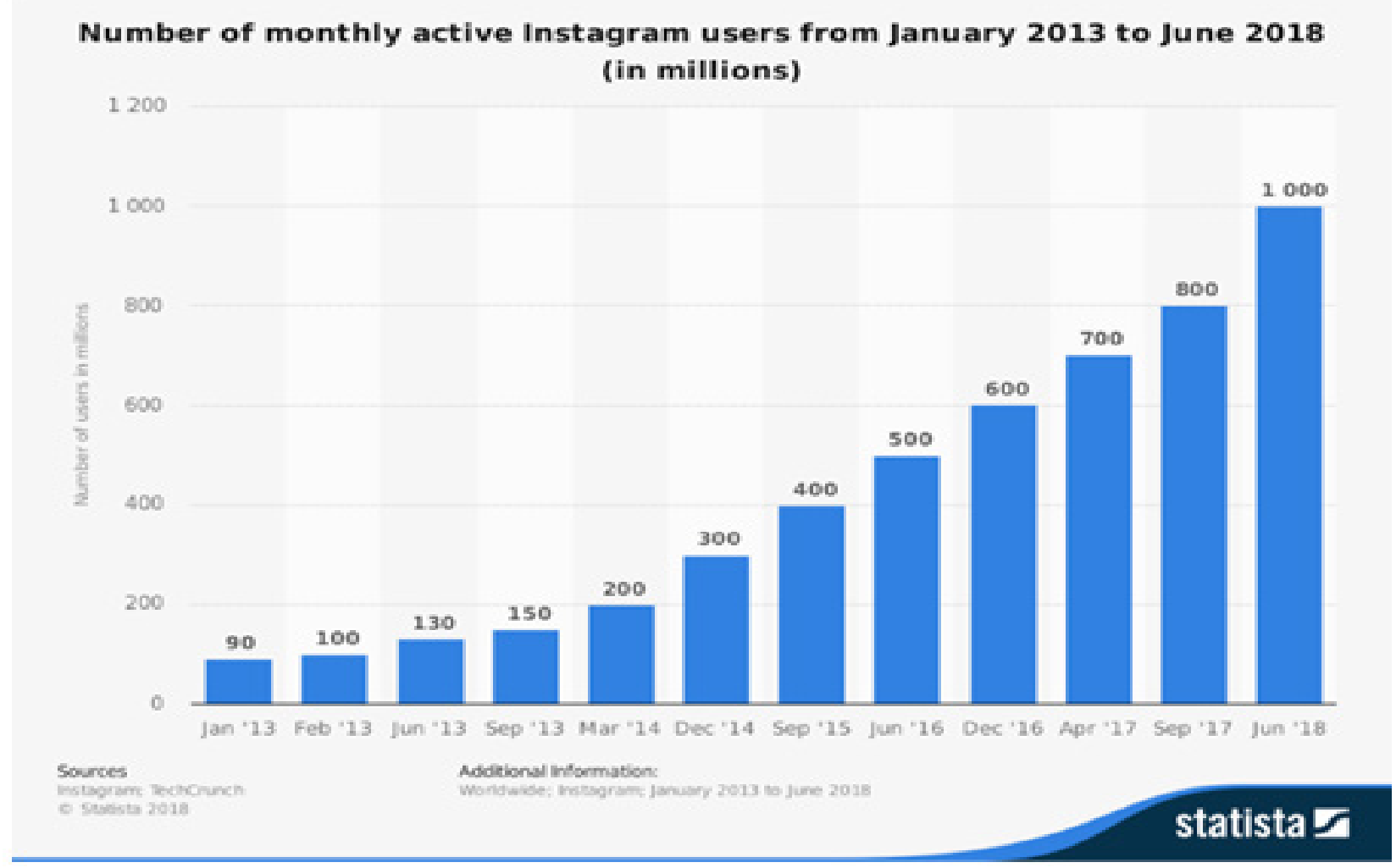

Sumber: Statista, 2019

Gambar 2 Angka Pengguna Aktif Instagram dari Bulan Januari 2013-Juni 2018

Data yang diungkapkan oleh Atiko dkk bertujuan untuk memasarkan potensi sebuah menjelaskan tingginya pengguna Instagram di daerah (Christian, Bangsa, \& Malkisedek, Indonesia yakni sebanyak $7 \%$ dari 88,1 juta 2018). Brand atau merk penting untuk pengguna Internet di Indonesia menggunakan dibangun oleh sebuah daerah karena dapat Instagram. Dalam kurang dari satu tahun, pengguna media sosial terus bertambah sebanyak menjadi pembeda dengan daerah lainnya yang menawarkan produk wisata sejenis (Helmi, 100 juta pengguna di seluruh dunia (Atiko, Sudrajat, \& Nasionalita, 2016). Dengan jumlah pengguna yang terus berkembang, Instagram dapat menjadi peluang sebagai sarana untuk mengoptimalkan promosi destinasi wisata yang diaplikasikan melalui destination branding.

Situmorang mengatakan bahwa destination branding merupakan serangkaian strategi yang 2008). Brand dapat memberikan makna simbolis dan psikologis di mata wisatawan. Proses membangun destination branding, tidak hanya melibatkan penciptaan perceived difference melalui iklan namun kualitas dari produk harus dikomunikasikan untuk mendukung brand image (Helmi, 2008). Dalam penelitian ini, yang dibahas lebih lanjut adalah produk 
wisata yang dimiliki sebuah daerah harus dikomunikasikan untuk mendukung brand image daerah tersebut. Melihat karakteristik dari media sosial khususnya Instagram yang dapat melampaui jangkauan waktu dan tempat serta memiliki fitur teks dan visual yang menarik menjadi sarana untuk mengoptimalkan upaya destination branding sebuah daerah.

Informasi yang disampaikan melalui Instagram untuk mempromosikan produk pariwisata yang bersifat visual lebih disukai oleh pengguna media sosial (Trihayuningtyas et al., 2018). Berdasarkan hasil penelitian yang dilakukan di Kabupaten Garut menunjukan bahwa responden mengetahui berbagai varian produk pariwisata dan merasa tertarik untuk mengetahui lebih lanjut mengenai destinasi wisata yang berada di Kabupaten Garut melalui postingan beberapa akun Instagram yang menampilkan potensi wisata di wilayah Kabupaten Garut (Trihayuningtyas et al., 2018).

Adanya respons berupa komentar dari pengguna Instagram yang menanyakan informasi produk, mengomentari postingan atau memberi like pada postingan menunjukan keinginan untuk berkunjung ke destinasi wisata yang dipromosikan melalui akun Instagram (Trihayuningtyas et al., 2018).

Selain itu, hasil penelitian yang dilakukan oleh Hikmawan \& Pradhanawati menjelaskan upaya place branding dapat dilakukan dengan menggunakan media sosial untuk memperkenalkan potensi di Taman Nasional Karimun Jawa kepada publik melalui berbagai fitur yang ada di media sosial. Gambargambar di objek wisata, akses menuju lokasi wisata, dan fasilitas yang dimiliki di Taman Nasional Karimun Jawa dapat dengan jelas disampaikan melalui media sosial (Hikmawan \& Pradhanawati, 2016). Proses place branding dapat dilakukan dengan cepat melalui media sosial yang menggunakan konsep consumer generated content. Konsep tersebut nantinya dapat memberikan sugesti kuat bagi calon wisatawan.

Media sosial memiliki peran yang kuat dalam upaya destination branding dan media sosial dapat membangun destination branding secara signifikan. Konten di media sosial dapat diciptakan oleh "organisasi pemasaran" dimana bukan hanya pengelola organisasi destinasi wisata namun konsumenpun turut berkepentingan untuk memasarkan potensi sebuah destinasi wisata melalui penyebaran informasi (Hikmawan \& Pradhanawati, 2016).

Bukan hanya keindahan dari suatu daerah yang menjadi faktor dalam menentukan destinasi wisata, faktor keamanan, dan resiko bencana alam juga menjadi pertimbangan konsumen dalam menentukan destinasi wisata dan memengaruhi destination branding sebuah wilayah. Informasi mengenai bencana alam 
dapat dikomunikasikan melalui media sosial khususnya Instagram. Misalnya informasi mengenai bencana, termasuk gempa bumi Haiti tahun 2010 dan badai pasir Sandy tahun 2012 (Anson, Watson, Wadhwa, \& Metz, 2017).

Selain itu, di daerah India Selatan, media sosial seperti Facebook dan WhatsApp telah dimanfaatkan menjadi forum komunikasi para aktivis sosial dalam kebencanaan. Hal tersebut karena peristiwa bencana alam membutuhkan sebuah wadah komunikasi agar dunia mengetahui nasib para korban bencana alam yang kemudian dapat menggugah para pengguna untuk melakukan tindakan penyelamatan dan memberikan bantuan (Bhuvana \& Arul Aram, 2019). Facebook dan WhatsApp digunakan dalam pengelolaan banjir Chennai tahun 2015, terutama oleh penduduk Kotturpuram dan Mudichur, dua daerah yang paling parah terkena dampaknya di kota tersebut. Berbagai informasi terkini yang terjadi di wilayah tertentu dapat memengaruhi destination branding dan dengan cepat dapat diinformasikan pada publik melalui media sosial.

Sama halnya dengan berbagai contoh penggunaan media sosial untuk menginformasikan bencana alam di suatu wilayah seperti contoh di atas, berbagai lembaga di Indonesia juga telah menyadari akan pentingnya mengelola media sosial dalam mendukung upaya destination branding wilayahnya. Salah satunya dilakukan oleh BPBD Kabupaten Pangandaran. Kabupaten Pangandaran merupakan salah satu Kabupaten yang terletak di Provinsi Jawa Barat dengan luas wilayah yakni 168.509 Ha dan luas laut 67.340 Ha. Kabupaten Pangandaran juga memiliki panjang pantai $91 \mathrm{Km}$ (WebPangandaranKab, 2019). Dengan luas wilayah tersebut, Kabupaten Pangandaran memiliki potensi yang sangat beragam terutama pada aspek wisata bahari yang terdiri dari objek wisata pantai dan sungai yang menjadi potensi terbesar dari kabupaten yang resmi didirikan pada tahun 2012 ini. Beragam objek wisata yang ada di Kabupaten Pangandaran adalah: "Pantai Madasari, Pantai Karapyak, dan wisata sungai yaitu Cukang Taneuh (Green Canyon), Citumang, dan Santirah. Tersedia fasilitas hotel dengan kelas yang bervariasi dan cukup lengkap, restoran dan tempat hiburan lainnya" (WebPangandaranKab, 2019).

Mengingat letak geografis Kabupaten Pangandaran yang strategis, selain potensi pariwisata yang dimiliki, wilayah ini juga memiliki resiko bencana alam yang cukup tinggi. Badan Penanggulangan Bencana Daerah (BPBD) Kabupaten Pangandaran, Jawa Barat mencatat sekitar 110 kejadian bencana alam selama 2018, mulai dari banjir, longsor, angin kencang, dan gempa bumi. Tsunami merupakan salah satu potensi bencana yang jarang terjadi 
namun dapat membuat jantung berdebar dan menimbulkan was-was, apalagi Pangandaran merupakan daerah wisata yang berbasis lingkungan. Saat ini Pangandaran baru memiliki dua early warning system yang masih berfungsi dengan baik, sedangkan pantai Pangandaran memiliki panjang sekitar $91 \mathrm{~km}$, idealnya untuk pantai sepanjang $91 \mathrm{~km}$ diperlukan sekitar 30 titik early warning system. Jika dilihat dari kerawanan bencana maka Pangandaran menempati urutan ke 16 rawan bencana dari 514 kabupaten/kota di Indonesia.

Melihat kondisi Kabupaten Pangandaran yang memiliki potensi pariwisata juga resiko bencana alam, diperlukan upaya mengoptimalkan destination branding melalui media sosial Instagram untuk menginformasikan core value Kabupaten Pangandaran sebagai destinasi wisata yang aman dan tanggap bencana. Sehingga pengunjung dapat menikmati potensi wisata di daerah Kabupaten Pangandaran dengan nyaman. Dengan mengoptimalkan konten di akun Instagram BPBD Kabupaten Pangandaran ini nantinya akan mendukung destination branding Kabupaten Pangandaran dalam mewujudkan salah satu misi Kabupaten Pangandaran yakni "Kabupaten Pangandaran Pada tahun 2025 menjadi kabupaten pariwisata yang mendunia, tempat tinggal yang aman dan nyaman berlandaskan norma agama" (WebPangandaranKab, 2017).
Penelitian ini bertujuan untuk mengetahui bagaimana penggunaan media sosial dalam hal ini Instagram oleh Badan Penanggulangan Bencana Daerah (BPBD) Kabupaten Pangandaran Jawa Barat untuk mengoptimalkan destination branding Kabupaten Pangandaran sebagai destinasi wisata yang aman dan tanggap bencana.

\section{METODE PENELITIAN}

Metode penelitian yang digunakan pada penelitian ini adalah metode deskriptif dengan teknik analisis kualitatif. Fraenkel \& Wallen mengemukakan bahwa penelitian kualitatif berfokus pada proses yang terjadi bukan pada hasil. Untuk itu di dalam penelitian ini peneliti berusaha memahami bagaimana sebuah fenomena itu terjadi (Creswell, 2002). Tujuan dari penelitian ini yaitu menggambarkan atau mendeskripsikan objek dan fenomena yang berkaitan dengan penggunaan media sosial terutama Instagram oleh BPBD Kabupaten Pangandaran terutama dalam mengoptimalkan destination branding Kabupaten Pangandaran sebagai destinasi wisata yang aman dan tanggap bencana.

Teknik pengumpulan data yang dilakukan melalui dua cara: 1) Pengumpulan data primer dilakukan dengan wawancara bebas dengan mengacu pada instrumen penelitian berupa daftar wawancaran. Namun disini daftar 
wawancara digunakan hanya sebagai pedoman, ketika wawancara berlangsung, topik dan pertanyaan berkembang sesuai dengan diskusi yang berkembang. Teknik pemilihan informan secara purposif memilih informan secara sengaja dan tidak acak. Informan yang dipilih adalah mereka yang memang diasumsikan dapat memberi informasi sehubungan dengan penelitian ini. Pada dasarnya jumlah informan dalam penelitian kualitatif tergantung dari kebutuhan data yang diperlukan. Adapun informan yang diwawancarai adalah a) Kepala pelaksana BPBD Kab. Pangandaran; b) tim media sosial BPBD Kab. Pangandaran; dan c) petugas piket harian di kantor BPBD Kab. Pangandaran. 2) pengumpulan data sekunder yaitu melalui pencarian dan penemuan bukti-bukti. Metode ini merupakan metode pengumpulan data yang berasal dari sumber non-manusia. Sumber-sumber informasi non-manusia ini seringkali diabaikan dalam penelitian kualitatif, padahal sumber ini kebanyakan sudah tersedia dan siap pakai. Dokumen berguna karena dapat memberikan latar belakang yang lebih luas mengenai pokok penelitian. Selain dokumen yang tertulis, foto juga merupakan salah satu bahan dokumenter. Foto bermanfaat sebagai sumber informasi karena mampu menggambarkan peristiwa yang terjadi. Tetapi dalam penelitian ini tidak digunakan kamera sebagai alat pencari data secara sembarangan, sebab orang akan menjadi curiga. Kamera digunakan ketika sudah ada kedekatan dan kepercayaan dari objek penelitian dengan terlebih dahulu meminta ijin ketika akan menggunakannya.

\section{HASIL DAN PEMBAHASAN}

Berbicara mengenai standar alat kebencanaan, menurut Kepala BPBD Pangandaran saat ini sarana prasarana masih sangat minim, jika dibandingkan di antara 27 Kabupaten di Jawa Barat. Hal ini disebabkan oleh kemampuan daerah yang berbeda-beda. Sedangkan untuk sarana pasca bencana sudah cukup baik yaitu shelter pengungsian atau Tempat Evakuasi Sementara (TES) seharga 24 milyar yang dapat menampung 6000 orang disumbang oleh Kementrian Perhubungan.

Untuk early warning system tsunami mendapat bantuan dari BMKG sebanyak dua buah, kemudian untuk peralatan early warning system longsor dan banjir mendapat bantuan dari Bank Indonesia sebanyak 4 buah. Namun peralatan tersebut masih jauh dari ideal karena titik longsor ada sekitar 800 titik yang dipasang baru 4 untuk longsor dan 1 untuk titik banjir. Bantuan lainnya didapat dari dana dana CSR BUMN, BUMD, dan perusahaan swasta yang ada di Kabupaten Pangandaran.

Tingginya potensi bencana di Pangandaran menjadi salah satu latar belakang perlunya 
upaya mengoptimalkan destination branding Kabupaten Pangandaran sebagai destinasi wisata yang aman dan tanggap bencana mengingat banyaknya potensi wisata yang ada di Kabupaten Pangandaran. Bencana alam menjadi salah satu faktor pertimbangan calon wisatawan dalam menentukan destinasi wisata. Sehingga upaya BPBD Kabupaten Pangandaran dalam penggunaan media sosial Instagram dalam mengoptimalkan destination branding Kabupaten Pangandaran penting untuk dilakukan.

Bencana alam berdampak negatif pada semua aspek kehidupan seseorang. Bencana alam tidak hanya menghancurkan tatanan fisik dengan menghancurkan infrastruktur, lansekap, properti perumahan dan bisnis, itu juga dapat memengaruhi kondisi emosional individu/ masyarakat setelah menyaksikan hilangnya nyawa dan kerusakan yang ditimbulkan. Selain dapat menyebabkan gangguan psikologis dan fisik yang begitu cepat, bencana juga memiliki konsekuensi jangka panjang, seperti kehilangan pekerjaan dan harta benda yang tidak dapat diatasi secara finansial, serta gangguan stres pascatrauma (Jamali, Nejat, Ghosh, Jin, \& Cao, 2019). Kehidupan sosial berkaitan erat dengan stabilitas kondisi lingkungan fisik, insfrastruktur dan interaksi sosial. Maka ketika terjadi bencana akan menyebabkan dampak negatif terhadap kondisi kehidupan masyarakat untuk waktu yang cukup lama, karena kerusakan yang terjadi akibat bencana tidak dapat dipulihkan dengan cepat, memerlukan waktu yang cukup lama.

Media sosial merupakan salah satu sumber informasi yang dirujuk oleh masyarakat pada saat ini, karena itu informasi yang diunggah di media sosial dapat menyebar dengan cepat dan luas (Kammerl \& Kramer, 2016). Salah satu alasan penggunaan Instagram oleh BPBD adalah sifatnya yang dapat menyebarkan pesan lewat visual mampu menggambarkan kondisi yang terjadi di lapangan dengan otentik dan jelas. Selain itu alasan lainnya adalah dari segi biaya murah, tidak memerlukan banyak orang untuk mengelolanya serta kecepatan dan jangkauan media sosial yang luas.

Sejak didirikan pada 2010, Instagram telah berkembang pesat menjadi salah satu forum media sosial terbesar di dunia, dengan lebih dari 700 juta pengguna terdaftar. Saat ini Instagram telah digunakan untuk pengembangan profesional dan pemanfaatan untuk pendidikan (Shafer, Johnson, Thomas, Johnson, \& Fishman, 2018); (Singh, Halgamuge, \& Moses, 2019).

Saat ini diperlukan sebuah media yang dapat memberikan gambaran situasi yang terperinci mengenai keadaan darurat bencana sehingga masyarakat dapat mengetahui kondisi yang terjadi dan dapat membantu mengurangi kesengsaraan melalui bantuan kemanusiaan. 
Media yang dapat menjangkau masyarakat dengan cepat dan memuat informasi visual mengenai kondisi di lapangan adalah Instagram (Teodorescu, 2015). Karakteristik media sosial tersebut dibutuhkan dalam mengoptimalkan destination branding karena pada dasarnya destination branding merupakan upaya untuk mempublikasikan citra sebuah wilayah pada publik.

Salah satu alasan penggunaan Instagram sebagai media informasi BPBD Kab. Pangandaran adalah dari kecepatan dan biaya yang murah, berikut kutipan wawancara dengan kepala BPBD Kab. Pangandaran:

"Perbedaaannya sih, lebih cepat medsos, lebih cepat sampai apalagi kalau dari sifatnya dari masyarakat kesini itu lebih cepat. Kalau ada bencana, kalau ada kejadian gitu kalau informasi biasa sih sama saja sebetulnya. Nah yang dibutuhkan ini kan kecepatan gerak, begitu terjadi ada informasi masuk kita kroscek benar atau tidak karena banyak bohong juga itu berita. Kayak disini ada informasi rumah tertimpa pohon, datang kesitu tidak ada atau ini ada rumah kebakaran ternyata sarang tawon yang dibakar. Nah itu butuh kroscek juga makanya kita punya tadi, teman FKDM disana untuk mengecek apa yang terjadi di lokasi lalu baru kita kesana. Jadi lebih cepat media yang ada di media sosial".

Untuk membahas mengenai penggunaan media sosial oleh Badan Penanggulangan Bencana Daerah (BPBD) Kabupaten Pangandaran digunakan konsep The Circular Model of Some dari Regina Luttrell yang terdiri dari membagikan (Share), mengoptimalkan
(Optimize), mengelola (Manage), dan melibatkan (Engage) (Luttrell, 2015). Konsep tersebut kemudian diaplikasikan pada tahapan destination branding diantaranya adalah: “(1) Market Investigation, (2) brand identity development, (3) brand launch and introduction: communicating the vision (4) brand implementation, dan (5) monitoring, evaluation and review." Pada penelitian Morgan \& Pitchard ini, tahap destination branding yang dianalisis meliputi Market Investigation, Brand Identity Development dan Monitoring, Evaluation and Review (Christian et al., 2018).

Pada tahap awal destination branding yaitu tahap Market Investigation dilakukan pemetaan potensi pasar dan melihat apa saja yang dapat dikembangkan dalam penyusunan strategi dilakukan oleh marketer daerah (Christian et al., 2018). Pada tahapan ini dapat diaplikasikan Proses Share pada media sosial. Proses share adalah proses ketika terjadi pemilihan media yang akan digunakan, siapa sasarannya, dan jenis media apa yang paling banyak digunakan oleh sasarannya. Hal ini menjadi upaya pemetaan potensi pasar atau target audiens. Ada dua tahapan yang dilakukan oleh BPBD Kabupaten Pangandaran yaitu pemilihan media Instagram dan menentukan target sasaran yang dapat meningkatkan kesadaran masyarakat mengenai kebencanaan.

Latar belakang pemilihan media Instagram 
sebagai media yang digunakan adalah masyarakat yang memerlukan informasi mengenai wilayah yang tanggap bencana sebagai pertimbangan dalam pemilihan destinasi wisata. Dengan menunjukan berbagai kegiatan yang mengedukasi masyarakat mengenai edukasi kebencanaan melalui akun Instagram BPBD Kab. Pangandaran, calon wisatawan dapat melihat upaya destination branding menjadi destinasi wisata yang aman dan tanggap bencana. Target dari penggunaan media sosial ini adalah masyarakat luas namun alokasi pembiayaan yang didapat oleh BPBD sangat minim sehingga dipilihlah media sosial yang secara biaya lebih murah dan tidak memerlukan banyak orang dalam mengelolanya. Selain itu saat ini tren media sosial sudah menjadi rujukan informasi masyarakat, hal tersebut sesuai dengan pernyataan Luttrell yang menyatakan bahwa sosial media dapat membantu untuk saling menyebarkan informasi dalam sebuah jaringan online (Luttrell, 2015).

"Justru kalau saya kan mikir gimana caranya, duit ga punya apa sih yang harus kita kerjakan tapi pingin mendunia, pingin dikenal orang ya main ini, main Instagram. Makanya orang lain tau ada kegiatan ini dan itu ya dari media. Bedanya dengan Facebook, Ig lebih banyak menampilkan foto sehingga lebih menarik masyarakat dan bisa memperlihatkan kondisi lapangan secara nyata" (Wawancara penelitian, 2019).

Salah satu alasan memanfaatkan Instagram untuk mengoptimalkan destination branding adalah karena lebih banyak menampilkan foto yang dapat menarik masyarakat serta mendeskripsikan keadaan lapangan tanpa harus melalui tulisan. Dengan kata lain, dengan menggunakan Instagram, pemberitaan tidak hanya berupa tulisan saja namun juga bisa dengan gambar foto yang menarik.

Atmoko mengemukakan, Instagram adalah sebuah aplikasi berbagi foto dan mengambil gambar atau foto yang menerapkan filter digital untuk mengubah tampilan efek foto, dan membagikannya ke berbagai layanan media sosial, termasuk milik Instagram sendiri (Atmoko, 2012). Instagram sendiri terdiri dari fitur-fitur seperti: 1) Homepage; 2) comments; 3) Explore; 4) Profil; dan 5) Newsfeed. Dapat dikatakan, keunggulan Instagram dapat dilihat dari fitur tersebut diantaranya dalam fitur homepage yang merupakan halaman utama yang menampilkan timeline foto dari sesama pengguna dan biasanya yang muncul adalah foto foto terbaru dari pengguna. Kemudian dengan fitur comments adalah layanan jejaring sosial dimana pengguna dapat berinteraksi dengan admin dan pengguna lain. Selanjutnya dengan fitur explore, pengguna dapat mencari fotofoto populer yang paling banyak disukai para pengguna Instagram, kemudian dengan fitur profil, pengguna dapat mengetahui secara detail mengenai informasi admin, dan yang terakhir 
adalah newsfeed yang merupakan fitur untuk menampilkan notifikasi berbagai aktivitas yang dilakukan pengguna, misalnya komentar pada foto yang diunggah, notifikasi Direct Message jika ada pengguna yang memberikan pesan private kepada admin atau pengguna lain.

Penentuan target sasaran dari media sosial ini adalah masyarakat yang menggunakan Instagram. Pengguna Instagram kian hari kian meningkat sehingga peluang pengguna memfollow akun@pusdalopspangandaran akan semakin besar. Hal ini diperkuat oleh hasil analisis dari Hootsuite dan We are Social, terkait penggunaan Instagram di Indonesia sepanjang awal tahun 2018. Dalam data tersebut menyebutkan bahwa Indonesia memiliki 53 juta jumlah pengguna aktif bulanan dan pengguna aktif Instagram dari total populasi sekitar 20 persen (Hootsuite \& We Are Social, 2019).

Target sasaran dari akun @ pusdalopspangandaran yang dikelola oleh BPBD Kabupaten Pangandaran adalah para pengguna Instagram khususnya Jawa Barat dan umumnya pengguna dari seluruh dunia. Jika salah seorang pengguna mendapatkan informasi dari media sosial tentang suatu peristiwa, pada umumnya mereka akan menyebarkan informasi tersebut kepada pengguna yang lain. Hal sesuai dengan karakteristik media sosial yang mengatakan bahwa media sosial membentuk

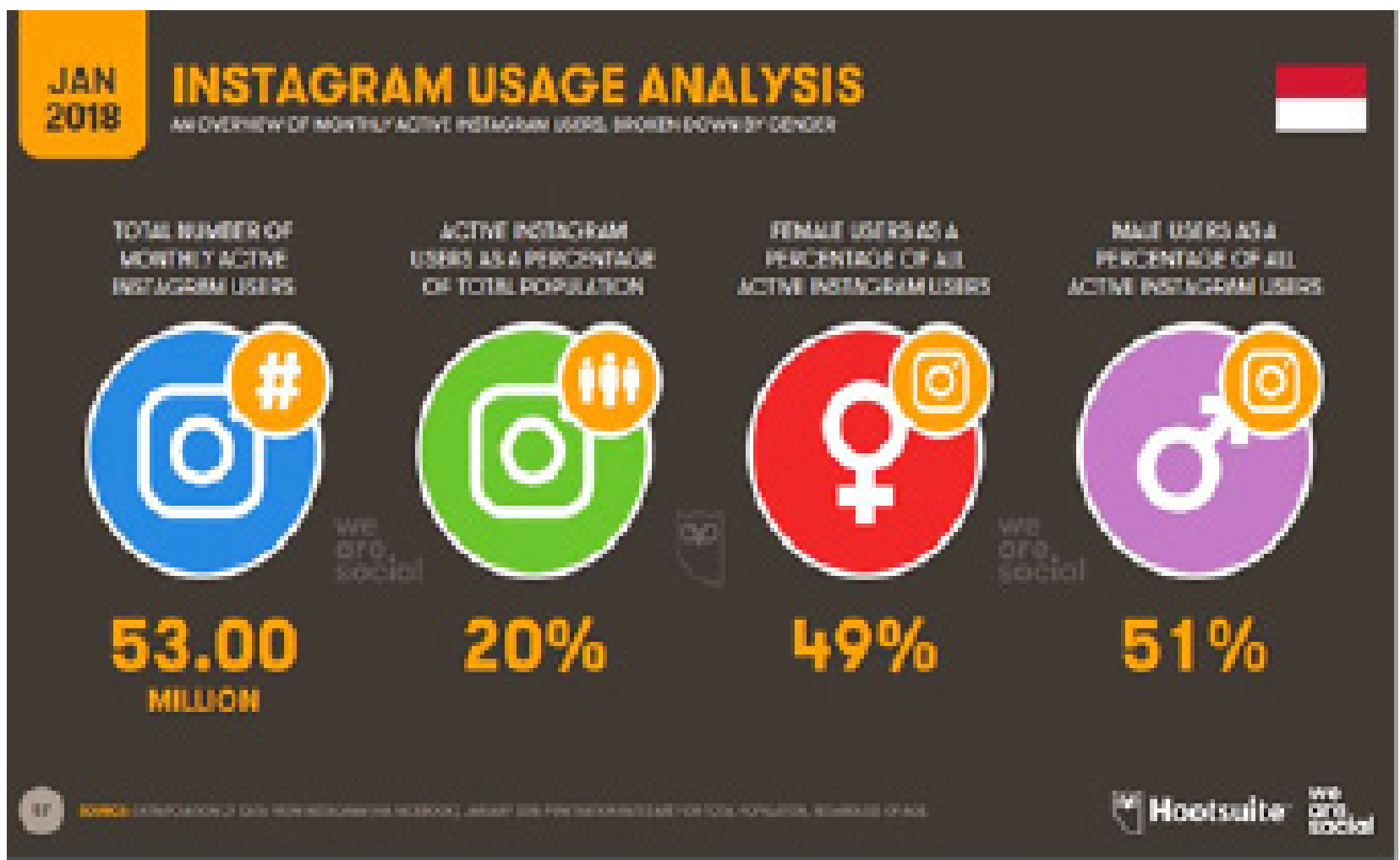

Sumber: Global Digital Report, 2018

Gambar 3 Pengguna Instagram di Indonesia Januari 2018 
jaringan di antara penggunanya (Nasrullah, 2015). Media sosial menyediakan medium bagi para penggunanya untuk terhubung secara online meskipun mereka tidak saling mengenal diantaranya membentuk jaringan sosial, yang pada akhirnya akan memuncukan nilai nilai baru di antara mereka. Di dalam jaringan tersebut mereka saling tukar menukar informasi, saling menyebarkan informasi dan saling bertukar opini terhadap informasi tersebut.

Pada tahap kedua yaitu tahap Brand Identity Development penting untuk dilakukan agar nilai brand dapat dikomunikasikan secara kohesif melalui Below The Line atau Above The Line sehingga mempertahankan kehadiran merek (Christian et al., 2018). Dari latar belakang penyebaran informasi mengenai edukasi penanggulangan bencana melalui akun Instagram BPBD Kab. Pangandaran, core value dari upaya destination branding ini adalah menginformasikan pada publik bahwa Kab. Pangandaran adalah destinasi wisata yang aman dan tanggap bencana. Tahap ini dapat dioptimalkan melalui Proses optimize yang berisikan mengenai konten pesan yang akan dibagikan menyangkut permasalahan, informasi mengenai suatu kejadian, peringatan dini terhadap bencana, mengemas pesan hingga mudah dipahami oleh khalayak sasaran, dan mengemas informasi yang menjadi kebutuhan khalayak dan mengoptimalkan core value destination branding Kab. Pangandaran. Salah satu kegiatan BPBD Kab. Pangandaran di Instagram dapat dilihat pada gambar 4.

Salah satu tugas dari BPPD Kab. Pangandaran memberikan informasi pada masyarakat ketika bencana terjadi yaitu pra bencana, darurat bencana dan pasca bencana. Pra bencana dilakukan dengan cara memberikan edukasi pada masyarakat. Saat ini sasaran pra bencana adalah anak anak SD, SMP dan ibu rumah tangga dengan alasan anakanak cepat dalam menerima pengetahuan baru, sedangkan ibu rumah tangga karena biasanya selalu ada di rumah ketika bencana terjadi. Berikut wawancara dengan kepala BPBD Kab.

Pangandaran:

"Pertama, saya sendiri orang pendidikan, saya lama bekerja di pendidikan 36 tahunan mungkin. Nah kesini baru 3 tahunan, pertama memanfaatkan modal itu. Yang kedua, anak itu yang paling efektif, gampang diberi ilmu, gampang menyerap ilmu, orang tua mah kan susah, yang akhirnya anak sendiri yang ngajar kepada orang tuanya. Sehingga pas kejadian gempa bumi kemarin, saya sampai menitikan air mata karena banyak orang tua yang mengabari "aduh pak haji, saya jadi tahu kalau sikap ada gempa itu harus seperti ini, ini" "dari siapa?" dari anaknya. Nah itu, luar biasanya pendidikan kepada anak itu bisa juga orang tuanya kebawa, bisa juga menularkan pada orang tuanya".

Selanjutnya pada saat darurat bencana dan pasca bencana, mulai dari kegiatan proses evakuasi, pemasangan tenda evakuasi, pendistribusian bantuan sosial, bantuan logistik, 


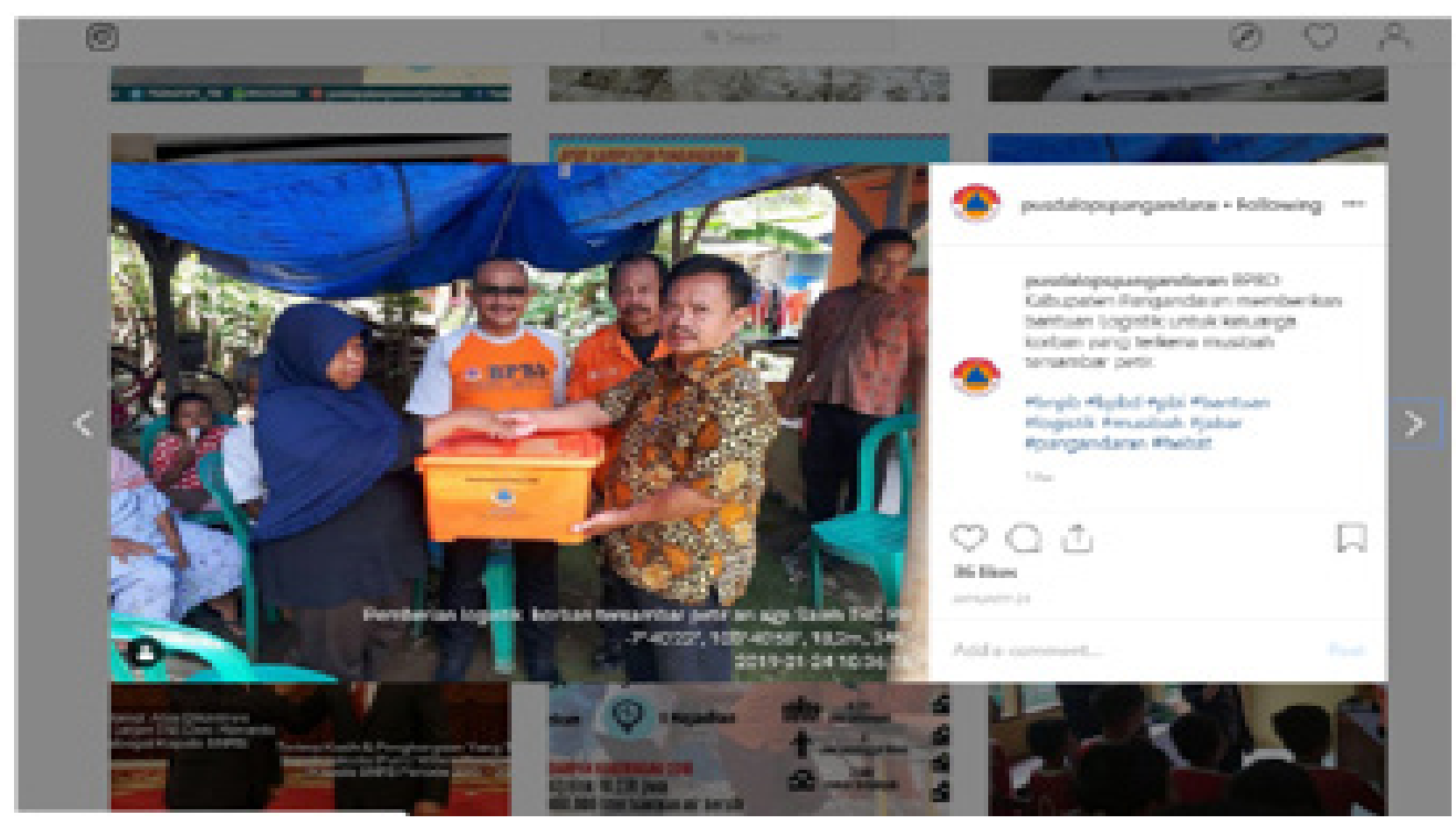

Sumber: Instagram, 2019

\section{Gambar 4 Foto kegiatan BPBD Kabupaten Pangandaran memberikan bantuan Logistik di @ pusdalopspangandaran}

serta pemulihan sarana prasarana maupun rumah warga yang rusak akibat bencana. Informasi tersebut dikemas secara visual dan diunggah di media Instagram dengan dilengkapi hashtag kebencanaan, agar memudahkan pengguna untuk mencari informasi mengenai bencana yang terjadi. Selain memuat informasi mengenai bencana yang terjadi, unggahan tersebut memperlihatkan kegiatan yang sudah dilakukan oleh berbagai pihak mulai dari pemerintah, lembaga masyarakat, maupun dari unsur masyarakat itu sendiri, sehingga para pengguna Instagram mengetahui proses penanggulangan bencana yang terjadi sudah sampai mana dan sudah melakukan apa saja.

Konten pesan dalam media sosial dalam tahapan optimalisasi sebaiknya pihak lembaga harus melihat, memperhatikan, dan mengukur menggunakan alat ukur media sosial untuk melihat perkembangan dan interaksi pengguna yang berkaitan dengan informasi yang diunggah (Luttrell, 2015). Namun, pihak BPBD belum melakukan pengukuran dengan menggunakan alat ukur media sosial. Pengukuran dan monitoring masih dilakukan dengan cara manual yaitu melihat satu-satu hasil postingan mereka, dan berusaha menjawab jika ada pertanyaan atau komentar yang ditujukan pada lembaga. Seharusnya pihak BPBD menggunakan tools untuk mengukur keaktifan, opini, pembelaan serta dampak dari hasil postingan mereka dengan menggunakan misalnya Melthwater Sysomos, 
Radian 6, Linkfluence, Spiral16. Sisi positifnya pihak admin@pusdalopspangandaran ikut berpartisipasi dan berinteraksi dengan pengguna melalui fitur comments dan fitur direct message.

Penyebaran informasi kebencanaan yang dilakukan oleh@pusdalopspangandaran di Instagram sudah cukup baik dengan ikutnya admin berpartisipasi secara aktif dengan pengguna melalui komunikasi secara langsung di kolom komentar. Hal ini sesuai dengan tujuan penggunaan media sosial sebagai tools oleh lembaga/organisasi yaitu untuk melakukan komunikasi dua arah dengan publiknya. Selain dapat menyerap aspirasi atau pendapat dari publiknya, media sosial juga dapat menjadi forum diskusi terbuka antara lembaga dengan publik (Hajati, Perbawasari, \& Hafiar, 2018).

Konten Instagram BPBD Kab. Pangandaran yang menjelaskan berbagai kegiatan edukasi kebencanaan secara mendetail dan mentargetkan segala lapisan masyarakat, dapat mengoptimalkan destination branding Kab. Pangandaran sebagai destinasi wisata yang tanggap bencana sehingga nantinya diharapkan dapat memberikan rasa aman bagi wisatawan.

Tahap monitoring, evaluation, and review. Tahap ini dilakukan evaluasi dan review untuk perbaikan selanjutnya melalui proses monitoring. Tahapan ini pertama diaplikasikan melalui proses manage dan engage dalam media sosial. Proses manage memuat bagaimana media sosial dikelola, dipantau dan diukur keefektifannya. Proses ini dapat dilakukan dengan cara pengamatan pada reaksi masyarakat terhadap pesan yang disampaikan.

Social media monitoring adalah sebuah metode analisa untuk melihat berbagai macam respons atau opini pengguna terhadap lembaga atau terhadap isu yang berkembang berkaitan dengan unggahan (Bekkers, Edwards, \& de Kool, 2013). Dalam melakukan proses manage, pengelola akun@pusdalopspangandaran melakukan dua proses yaitu media monitoring dan keterlibatan aktif dalam setiap komentar di postingan. Tujuan dari media monitoring adalah untuk mendapatkan wawasan dari pengguna Instagram mengenai pandangan atau persepsi mereka terhadap lembaga dan kegiatan yang dilakukan oleh mereka.

Praktik sosial media monitoring sudah banyak dilakukan oleh lembaga atau organisasi untuk mendapatkan gambaran mengenai opini masyarakat terhadap mereka. Salah satu contohnya organisasi publik di Belanda melakukan pemantauan media sosial. Adalah kontrol yang sangat strategis dan responsif ketika menghadapi pertanyaan normatif dalam hal transparansi, akuntabilitas, dan privasi (Bekkers et al., 2013).

Terkait dengan media monitoring, Lutrell mengemukakan bahwa setiap pengelola media sosial di lembaga dapat memahami hasil 
yang didapat dari konten yang diberikan serta mendapatkan gambaran mengenai ukuran keterlibatan dalam media sosial tersebut meliputi jumlah like, komentar, dan jumlah share (Lutrell, 2015).

Keterlibatan pengelola akun @ pusdalopspangandaran dapat dilihat dari balasan komentar sesuai dengan waktu komentar serta penggunaan bahasa yang yang ramah, mudah dipahami dan tidak kaku. Namun dikarenakan akun milik BPBD Kab. Pangandaran masih baru sehingga jumlah follower-nya belum begitu banyak yang berimplikasi pada kurangnya komunikasi dari para follower-nya.

Yang terakhir adalah proses engage yang meliputi proses keterlibatan antara pengelola media sosial dengan khalayak sasaran, mengelola tanggapan, dan menanggapi pertanyaan khalayak agar diketahui kebutuhan khalayak secara langsung. Proses ini selain dapat berinteraksi dengan pengguna, pengelola juga dapat mengetahui respons pengguna melalui respons yang diberikan di media sosial. Saatiniakun@pusdalopspangandaran memiliki 919 followers dengan jumlah postingan 68 buah. Untuk ukuran lembaga, followers dengan jumlah itu masih terbilang sedikit. Hal ini perlu menjadi perhatian pengelola akun mencari jalan bagaimana cara menambah followers sebanyak mungkin agar informasi yang diunggah dapat diterima oleh banyak pengguna. Salah satu kendala mengelola akun media massa adalah seringkali pengelola kewalahan untuk mengupdate berita atau informasi, sehingga banyak akun media sosial milik lembaga yang tidak berkembang.

Menurut Lutrell, tahap engage merupakan tahap yang sangat penting karena berhubungan dengan pengelolaan media sosial. Pada tahapan ini terjadi interaksi dan keterlibatan komunikasi antara pengelola akun dan pengguna media sosial tersebut (Lutrell, 2015). Hasil penelitian memperlihatkan masih kurangnya keterlibatan antara pengguna dengan pengelola media sosial. Pengguna sebagian besar hanya melihat dan memberikan like pada foto-foto yang diunggah oleh pengelola@pusdalopspangandaran. Sebaiknya hal ini menjadi pekerjaan rumah bagi pihak BPBD Kab. Pangandaran untuk melakukan evaluasi media sosial mengenai kurangnya keterlibatan komunikasi antara pengguna dan pengelola, serta masih sedikitnya followers akun tersebut.

\section{SIMPULAN}

Letak Kabupaten Pangandaran yang strategis menjadikan Kabupaten Pangandaran sebagai daerah dengan potensi pariwisata yang beragam salah satunya adalah wisata bahari terdiri dari wisata laut dan sungai. Namun dibalik beragamnya potensi wisata yang dimiliki, Kabupaten Pangandaran juga memiliki potensi 
bencana alam yang cukup tinggi. Untuk itu, Kabupaten Pangandaran melakukan berbagai upaya untuk membangun destination branding dengan core value yang berusaha ditanamkan adalah Kabupaten Pangandaran merupakan destinasi wisata yang aman dan tanggap bencana. Salah satu upaya yang dilakukan adalah dengan menggunakan media sosial Instagram BPBD Kabupaten Pangandaran sebagai sarana untuk menginformasikan core value destination branding Kabupaten Pangandaran.

Dalam tahap Tahap Market Investigation, dioptimalkan melalui proses share pada media sosial. Dalam proses share yaitu latar belakang pemilihan media Instagram sebagai media yang digunakan dikarenakan alokasi pembiayaan yang didapat oleh BPBD sangat minim sehingga dipilihlah media sosial yang secara biaya lebih murah dan tidak memerlukan banyak orang dalam mengelolanya. Selain itu saat ini tren media sosial sudah menjadi rujukan informasi masyarakat. Alasan lainnya dalam memanfaatkan Instagram adalah karena Instagram lebih banyak menampilkan foto yang dapat menarik masyarakat serta mendeskripsikan keadaan lapangan tanpa harus melalui tulisan. Dengan kata lain menggunakan Instagram pemberitaan tidak hanya berupa tulisan saja namun juga bisa dengan gambar foto yang menarik. Dengan dilakukannya proses share ini, dapat diketahui potensi pasar dan melihat apa saja yang dapat dikembangkan dalam penyusunan strategi dilakukan.

Dalam tahap Brand Identity Development, dioptimalkan melalui proses optimize pada pengelolaan media sosial. Dalam proses optimize pengelola akun@pusdalopspangandaran mengemas informasi mengenai edukasi bencana yaitu pra bencana, darurat bencana, dan pasca bencana. Pra bencana dilakukan dengan cara memberikan edukasi pada masyarakat. Saat ini sasaran pra bencana adalah anak anak SD, SMP dan ibu rumah tangga, dengan alasan anakanak cepat dalam menerima pengetahuan baru, sedangkan ibu rumah tangga karena biasanya selalu ada di rumah ketika bencana terjadi. Pesan yang ingin disampaikan oleh pengelola akun Instagram menunjukan kegiatan edukasi kebencanaan secara terperinci sehingga dapat mendukung core value destination branding. Hal ini penting dilakukan karena brand harus dikomunikasikan secara kohesif kepada publik.

Dalam Tahap monitoring, evaluation and review. Tahap ini diaplikasikan pada proses manage dan engage. Dalam melakukan proses manage pengelola akun@ pusdalopspangandaran melakukan dua proses yaitu media monitoring dan keterlibatan aktif dalam setiap komentar di postingan. Tujuan dari media monitoring adalah untuk mendapatkan wawasan dari pengguna Instagram mengenai pandangan atau persepsi mereka terhadap 
lembaga dan kegiatan yang dilakukan oleh mereka. Dalam proses engage yang meliputi proses keterlibatan antara pengelola media sosial dengan khalayak sasaran. Saat ini akun @pusdalops Pangandaran memiliki jumlah follower yang masih terbatas dan untuk ukuran lembaga jumlah followers sejumlah itu masih terbilang sedikit. Hal ini perlu menjadi perhatian pengelola akun mencari jalan bagaimana cara menambah followers sebanyak mungkin agar informasi yang diunggah dapat diterima oleh banyak pengguna. Salah satu kendala mengelola akun media massa adalah seringkali pengelola kewalahan untuk mengupdate berita atau informasi, sehingga banyak akun media sosial milik lembaga yang tidak berkembang. Perlu diperhatikan kembali pada proses engage, karena respons dari pengguna dapat menjadi bahan review dan perbaikan untuk program selanjutnya.

\section{DAFTAR PUSTAKA}

Adhrianti,L.(2016). Digitalisasi public relations bagi penguatan citra pemerintah daerah. Prosiding Seminar Nasional Komunikasi 2016 (pp. 115-125).

Anson, S., Watson, H., Wadhwa, K., \& Metz, K. (2017). Analysing social media data for disaster preparedness: Understanding the opportunities and barriers faced by humanitarian actors. International Journal of Disaster Risk Reduction, 21, 131-139. https://doi.org/10.1016/j.ijdrr.2016.11.014.

Arora, A., Bansal, S., Kandpal, C., Aswani, R.,
\& Dwivedi, Y. (2019). Measuring social media influencer index- insights from facebook, Twitter and Instagram. Journal of Retailing and Consumer Services, 49 (February), 86-101. https://doi.org/https:// doi.org/10.1016/j.jretconser.2019.03.012.

Atiko, G., Sudrajat, R. H., \& Nasionalita, K. (2016). Analisis strategi promosi pariwisata melalui media sosial oleh Kementerian Pariwisata RI. Jurnal Sosiotek, 15(3), 378389.

Atmoko, B. (2012). Instagram handbook tips fotografi ponsel. Jakarta: Media Kita.

Bekkers, V., Edwards, A., \& de Kool, D. (2013). Social media monitoring: responsive governance in the shadow of surveillance? Government Information Quarterly, 30(4), 335-342. https://doi.org/10.1016/j. giq.2013.05.024.

Bhuvana, N., \& Arul Aram, I. (2019). Facebook and Whatsapp as disaster management tools during the Chennai (India) floods of 2015. International Journal of Disaster Risk Reduction, (March), 101135. https:// doi.org/10.1016/j.ijdrr.2019.101135.

Casaló, L. V., Flavián, C., \& Ibáñez-Sánchez, S. (2018). Influencers on Instagram: antecedents and consequences of opinion leadership. Journal of Business Research, (October 2017). https://doi.org/10.1016/j. jbusres.2018.07.005.

Christian, J. A., Bangsa, P. G., \& Malkisedek, M. H. (2018). Perancangan media komunikasi visual destination branding kampung lawas maspati Kota Surabaya. DKV Adiwarna, $1(12), 1-11$.

Creswell, J. (2002). Qualitative inquiry and research design: choosing among five tradition. Thousand Oaks: Sage Publication.

Hajati, R. P., Perbawasari, S., \& Hafiar, H. 
(2018). Manajemen aktivitas media sosial akun Instagram@indonesiabaik.id. Meta Communication, 3(2).

Helmi, S. (2008). Destination brand: membangun keunggulan bersaing daerah. Wahana Hijau, 4 (March), 79-86. https:// doi.org/10.13140/RG.2.2.24164.99209.

Hidayatullah, T., Maya, R., Sabrina, R., Artanti, D., \& Kania, D. D. (2018). Marketing strategy for tour operator on social media (Instagram) in promoting tour packages to tourist attraction in Indonesia. Global Research on Sustainable Transport and Logistic. https://doi.org/ISSN : 2622-5778.

Hikmawan, Y. \& Pradhanawati, A. (2016). Analisis keterkaitan media sosial, word of mouth, potensi wisata, dan praktik place branding di Taman Nasional Karimun Jawa. Jurnal Ilmu Administrasi Bisnis, $5(3), 1-12$.

Hootsuite \& We Are Social. (2019). Digital 2019 Indonesia. Retrieved from https:// hootsuite.com/pages/digital-in-2019.

Jamali, M., Nejat, A., Ghosh, S., Jin, F., \& Cao, G. (2019). Social media data and postdisaster recovery. International Journal of Information Management, 44 (September 2018), 25-37. https://doi.org/10.1016/j. ijinfomgt.2018.09.005.

Kammerl, R. \& Kramer, M. (2016). The changing media environment and its impact on socialization processes in families. Studies in Communication Sciences, 16(1), 21-27. https://doi.org/10.1016/j. scoms.2016.04.004.

Luttrell, R. (2015). Social media: how to enggae, share and connect. London: Rowman \& Littlefield.

Nasrullah, R. (2015). Media sosial perspektif komunikasi, budaya dan sosioteknologi. Bandung: Simbiosa Rekatama Media.
Reza, F. (2016). Strategi promosi penjualan. Jurnal Kajian Komunikasi, 4(1), 64-74. https://doi.org/10.24198/jkk.v4i1.6179.

Shafer, S., Johnson, M. B., Thomas, R. B., Johnson, P. T., \& Fishman, E. K. (2018). Instagram as a vehicle for education: what radiology educators need to know. Academic Radiology, 25(6), 819-822. https://doi.org/10.1016/j.acra.2018.03.017.

Singh, A., Halgamuge, M. N., \& Moses, B. (2019). An analysis of demographic and behavior trends using social media: Facebook, Twitter, and Instagram. Social Network Analytics. https://doi.org/10.1016/ b978-0-12-815458-8.00005-0.

Statista. (2019). Number of monthly active Instagram users from January 2013 to June 2018. Retrieved from https://www.statista. com/statistics/253577/number-of-monthlyactive-Instagram-users/.

Teodorescu, H. N. (2015). Using analytics and social media for monitoring and mitigation of social disasters. Procedia Engineering, 107, 325-334. https://doi.org/10.1016/j. proeng.2015.06.088.

Trihayuningtyas, E., Wulandari, W., Adriani, Y., \& Sarasvati. (2018). Media sosial sebagai sarana informasi dan promosi pariwisata bagi generasi $\mathrm{z}$ di Kabupaten Garut. Tourism Scientific Journal, 4, 1-22.

Watie, E. D. S. (2017). Komunikasi dan media sosial. Jurnal The Messenger, 3(2), 69. https://doi.org/10.26623/themessenger. v3i2.270.

WebPangandaranKab. (2019). Selayang pandang Pangandaran. Retrieved from http://web.pangandarankab.go.id/public/ profile/profil-kabupaten-pangandaran.

Wijaya, S. W. (2016). Media sosial bagi Desa wisata: sebuah kajian konseptual. Media Teknika Jurnal Teknologi, 11(1), 55-59. 